\title{
The Media and Public Agendas Testing for Media Effects in Argentina During 2003-2008
}

\author{
Juan Carlos Cuestas, Sebastián Freille y Patricio O'Gorman
}

Revista de Economía y Estadística, Cuarta Época, Vol. 47, No. 1 (2009), pp. 97-124.

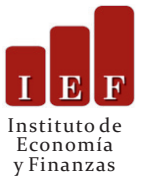

La Revista de Economía y Estadística, se edita desde el año 1939. Es una publicación semestral del Instituto de Economía y Finanzas (IEF), Facultad de Ciencias Económicas, Universidad Nacional de

Córdoba, Av. Valparaíso s/n, Ciudad Universitaria. X5000HRV, Córdoba, Argentina.

Teléfono: 00 - 54 - 351 - 4437300 interno 253.

Contacto: rev eco estad@eco.unc.edu.ar

y Finanzas

Dirección web http://revistas.unc.edu.ar/index.php/REyE/index

Cómo citar este documento:

Cuestas, J., Freille S. y O'Gorman P. (2009). The Media and Public Agendas Testing for Media Effects in Argentina During 2003-2008. Revista de Economía y Estadística, Cuarta Época, Vol. 47, No. 1, pp. 97-124.

Disponible en: <http://revistas.unc.edu.ar/index.php/REyE/article/view/3859>

El Portal de Revistas de la Universidad Nacional de Córdoba es un espacio destinado a la difusión de las investigaciones realizadas por los miembros de la Universidad y a los contenidos académicos y culturales desarrollados en las revistas electrónicas de la Universidad Nacional de Córdoba. Considerando que la Ciencia es un recurso público, es que la Universidad ofrece a toda la comunidad, el acceso libre de su producción científica, académica y cultural.

http://revistas.unc.edu.ar/index.php/index

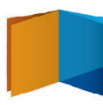




\section{The Media and Public Agendas Testing for Media Effects in Argentina During 2003-2008*}

\section{Juan Carlos Cuestas}

Nottingham Trent University

SEbastián FreilleE ${ }^{\#}$

Universidad Católica de Córdoba Universidad Nacional de Córdoba CONICET**

\section{Patricio O'Gorman}

Universidad de Palermo

\section{Abstract}

In this paper we examine the presence of agenda-setting effects by the print media in Argentina from June 2003 to December 2008. Using previously unavailable monthly data on newspapers mentions we test two hypotheses about the relationship between the different agendas. We find support for the hypothesis that there were media effects during our period of analysis. More specifically, we find that the total number of newspaper mentions of the President positively influenced public confidence in the government. Finally, there is also evidence of a strong and stable rela-

* We would like to thank an anonymous referee for his helpful comments and insightful suggestions. We would also like to thank Pedro Moncarz, Ivan Iturralde and Ricardo Descalzi for their comments. All errors and shortcomings are our own.

\# Corresponding author: Universidad Católica de Córdoba, Facultad de Ciencia Política y Relaciones Internacionales, Campus Universitario - Cno. Alta Gracia Km. 7.5 (5000), Córdoba, Argentina. Telephone: +543516754216. Email: sfreille@conicet.gov.ar

**Sebastian Freille acknowledges financial support from the Consejo Nacional de Investigaciones Científicas y Técnicas (CONICET) through a Postdoctoral Grant for the period 2009-2011. 
tionship between the total number of economic news and leading economic indicators.

Keywords: Agenda-setting, Public Opinion, Cointegration, Media Effects.

JEL Code: L82, E66.

\section{RESUMEN}

En este trabajo investigamos la presencia de efectos de la agenda de los medios en Argentina desde Junio de 2003 a Diciembre de 2008. Usando una base de datos construida a partir de menciones en periódicos, investigamos dos hipótesis sobre la relación entre las diferentes agendas. Encontramos que existen efectos de agenda significativos durante el período de análisis. Más específicamente, encontramos que el número total de menciones del Presidente afecta positivamente la confianza del público en el gobierno. Finalmente, también encontramos evidencia de una relación estrecha y estable entre el número total de menciones de noticias económicas y la evolución de los principales indicadores económicos.

Palabras clave: Agenda-setting, Opinión Pública, Cointegración, Efectos de Medios.

Código JEL: L82, E66.

\section{BACKGROUND AND MOTIVATION}

The idea that the news media have the ability and power to set the agenda of a nation by means of influencing public perception was originally suggested by Walter Lipmann in his book Public Opinion. The presumption behind this is that the print and broadcast media are able to create "pictures in our heads" that influence the way we perceive the actual events. In this way, the news media may be seen as powerful intermediaries between politicians and the public. More importantly, the agenda that is put forward by the media may differ from the political agenda and this may have several interesting implications concerning office power, electoral outcomes and party politics. Several empirical studies [Funkhouser (1973), McCombs and Shaw (1977), Smith (1987), Eaton (1989), Brosius and Kepplinger (1990) and King (1994)] $]^{1}$ provided support to the hypothesis

1. The studies mentioned vary in depth and coverage. While Funkhouser (1973) and McCombs and Shaw (1977) extend the methodological design of the Chapel Hill study using US data, Smith (1987), Eaton (1989) and Brosius and Kepplinger (1990) all use longitudinal data for various countries. 
developed by McCombs and Shaw (1972), suggesting a close relationship between the news media agenda and the public agenda.

Empirical research in this field is relevant for several reasons. Firstly, although the existence of agenda-setting effects has been widely documented in the literature, their significance may vary for different topics and audiences. Secondly, the existence of a relationship between the different agendas tells only part of the story; we are also interested in knowing the direction of this relationship and its evolution. Thirdly, agenda-effects may also bring about other political effects -coattails, accountability and party structure- which may in turn have an effect on democracy and development. Finally, research on this topic is important to understand the design of public policy; both the incumbents and the opposition take into account the public agenda when structuring their electoral promises and official policies.

Our focus on Argentina during this time period responds to a variety of reasons. The starting point in our sample coincides with the time when former President Nestor Kirchner began his constitutional term in office. In addition to covering the full four-year period, our sample also includes the first year in office of Cristina Fernández de Kirchner as President. The reason for including the early period of this latter administration is that there was virtually no change in the economic conditions, government policies and management style. It is also interesting to note that due to Nestor Kirchner's direct and personalist style, his relationship with the news media was often a wayward one. Indeed, several reports alerted of a worsening of press freedom standards during Nestor Kirchner's mandate ${ }^{2}$. Moreover, this is a particularly relevant period considering the number of high-profile cases and scandals involving government officials that were extensively covered by the news media. Finally, we are also interested to hypothesize whether the relationship between the different agendas had any impact on the build up and outcome of the 2007 Presidential election.

The relationship between the government and the mass media has been influenced by actions from other relevant actors. So much so, in fact,

2. See for example the Freedom House summary paper "Press Freedom in 2006: Growing threats to media independence". Other sources of criticism of Nestor Kirchner's administration's handling of press freedom are the Reporters Without Borders 2006 Annual Report and the two country reports of the Sociedad Interamericana de Prensa for the year 2005 
that formal complaints have been filed at the IPS (Interamerican Press Society) due to the attacks suffered by the two leading newspapers, Clarín and La Nación, when the Truck-drivers' Union -considered by some analysts as ideologically close to the government- asking for better wages blocked the deliveries of these newspapers to the news stands. This was very much condemned and considered an attack against democracy and freedom of speech, and introduced yet additional nuances to the relationship between the government and the media.

In our study, we raise the following issues:

- Analyse the print media coverage of the population's main concerns. The two most relevant daily newspapers are considered as "media".

- Analyse ex-President's Nestor Kirchner's public approval, as portrayed by the media and as seen in surveys.

- Examine the relationship between the media and public agendas and the ex-President's approval.

Although the empirical literature on agenda-setting comprises more than 300 studies, only a small proportion of these focus on developing countries. To the best of our knowledge, there is only a handful of studies addressing potential media effects for Argentina [Rey Lennon (1998), Bavastro and Szusterman (2003) and Waisbord (1993)] although our study uses a new dataset and modern econometric techniques in order to explore these issues in greater detail. Our study contributes to this latter literature and represents an attempt to tackle these issues in a more systematic and comprehensive way. Using a newly assembled dataset including monthly data for the media agenda -taken from daily coverage of the two main national newspapers La Nacion and Clarin-, public agenda measures derived from public opinion polls and political agenda from various surveys, we develop and test different hypotheses about the relationship between these agendas. Furthermore, we use a variety of econometric methods that allow us to explore not only individual characteristics of the time series but also their relationship over time.

The remainder of the paper is organised as follows. The next section presents a brief summary of the characteristics of the print media in Argentina and highlights important events of media involvement. In the third section we provide some theoretical background on the nature and 
relationship of the different types of agenda. Next, we briefly review the key literature and formulate the hypotheses to be examined. In the next section, we describe the methodology and data and discuss the econometric results. The last section summarizes the findings and implications of our analysis.

\section{The PRINT Media in Argentina}

Clarín and La Nación are the two leading newspapers in Argentina today. They both have very different and very rich histories: the former is over 100 years old and is considered by many the most elitist newspaper around, usually accused of a right-winger and pro-military slant; the latter has just turned 60 years and is three times as popular as La Nación, many times labeled as a populist news-source. It is also interesting to note that Clarín and La Nación are the main "generalist" papers in Argentina, as opposed to economically-oriented papers such as Ambito Financiero and Cronista Comercial. While Clarín and La Nación have daily circulation of over one hundred thousand papers, the latter papers have circulations in the range of 70 and 40 thousand respectively. Since these two publications have an economic focus already, we could not rule out the possibility that they show a certain bias towards the type of news we are looking to analyse among all of the news categories. Figure 1 shows average circulation for the two papers included in our sample.

For the past few decades, these two papers have been at the forefront of news-gathering and informing the population. The advent of TV (color TV arrived in Argentina in time for the 1976 World Cup and cable TV towards the mid-eighties) generated stiff competition from the air TV channels, which soon captured the lion's share of people's attention. However, newspapers retained a significant stronghold on people's minds, especially so since the same conglomerates who owned TV channels also owned newspapers, and they used multiple communication channels for a more effective news-propagation model. This decrease in relative importance can be observed in the thousands of average daily sales above. 
Figure 1

Clarin and La Nación average circulation

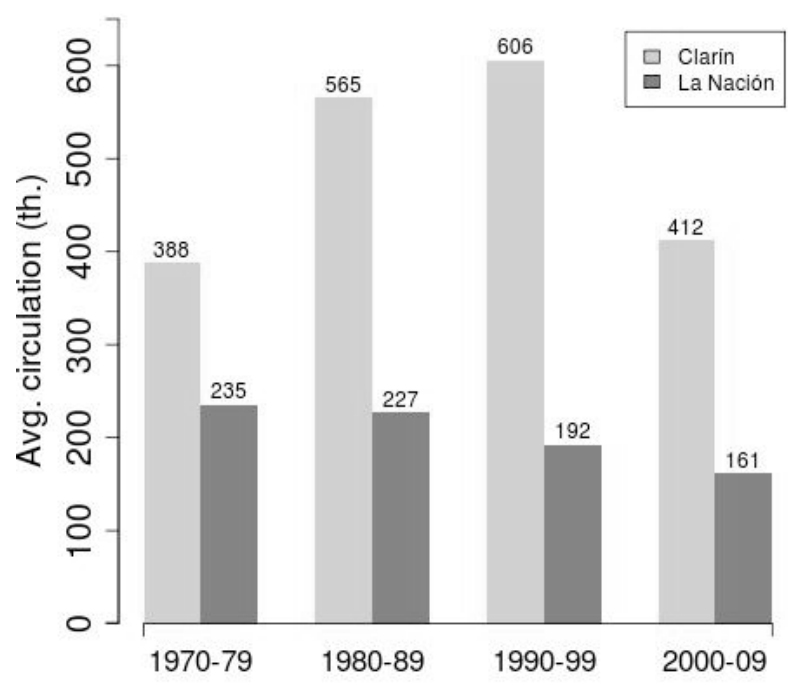

Source: La Cultura del Entretenimiento, Fenómeno Mundial. El Caso Argentino, Editorial Universidad de Palermo, Colección Management y Marketing, Año 2008.

However, the format of newspaper stands in Argentina puts the newspapers front-pages right in front of you, so it appears as if a great many people are exposed to newspapers although these are not included in the sales data mentioned before. Similarly, most restaurants/bars regularly purchase print copies of the papers, to which a large number of non-buyers are also exposed to and, ultimately even affected by those front-pages and potentially their sentiment (or lack thereof). Both these trends, plus the media concentration and multi-channel delivery approach, broaden the reach of the newspapers and all go unaccounted for in the sales figures. If we add the online companion sites, then we could have a closer idea as to the actual reach.

As is the case in many large cities throughout the world, the newspaper industry is enduring tough times in Argentina. Circulation is generally down, and as technology leaks into every aspect of people's lives, competition for the readers' attention intensifies for the written press.

As far as the political stance of the two papers, there are marked differences. La Nación has held a very critical view of basically all govern- 
ments since 2001, so the government assumes a predominantly pessimistic view of their actions, but only feel relatively threatened because they associate La Nación with the country's once-ruling aristocracy and agribusinessmen, without forgetting that this paper's circulation represents typically a quarter of Clarín's.

Clarín, on the other hand, seemed to side with Néstor Kirchner early on during his administration, although not unwaveringly. The advent of the soy export tax subsidies in early 2008 pitted the government against an impromptu coalition of rural factions anchored in demonstrations of popular support, particularly among the middle class. Clarin's editorial line had been gradually changing over the last two years portraying the government in a less positive light and the rural conflict seemed to accentuate this trend. Consequently, the relationship between the leading print media and the government suffered a gradual deterioration since both parties decided to follow their own agenda. The fact that neither ex-president Néstor Kirchner nor his wife and successor, President Cristina Fernández de Kirchner, have had a very positive and collaborative relationship with traditional media did not help the case, and both escalated positions in what became an all-out-war towards the beginning of 2010 .

Industry concentration, as we said, mitigates the fact that written media is on a downward trend, since it is the same companies that own TV, cable and Internet media (see Figure 1). This situation is likely to be modified, however, if the government is successful in passing new legislation seeking to introduce changes in media ownership and concentration. There are several proposed changes currently being discussed but the most conflicting are related with limiting the number of broadcasting licenses owned by a company and especially regarding the duration of the time period to be set for the "delicensing" process to be completed by companies exceeding the statutory limit.

Jorge Fontevecchia, head of Grupo Perfil and magazine Noticias -widely viewed as strong opposers to the Kirchner regime- had something very interesting to say about the clash between the government and Clarin: "In summary, media chose between 4 viable stances: technical or pure ... which is always critical much like the American "watchdog"; the ideological, which, consistent with its belief system, criticizes or praises whoever rejects or accepts its ideas, and which over the years might favor a government and criticize another, while maintaining its coherence; the utilitarian, whose normal version applauds whoever pays of favors it, and in its extreme 
version criticizes those who haven't paid yet or who oppose those who have; and the market-oriented which seeks to please the greatest amount of consumers. The Government's mistake was to have confused Clarin's market-oriented style with a utilitarian one which always has a price. Clarin has no price when the option is to go against the public opinion, which does not prevent it from profiting from credulous governments who think they can dominate it on topics that don't clash with public opinion." (Jorge Fontevecchia, "Por qué tan pronto", Diario Perfil, Editorial Sábado 12 de Abril de 2008 Año III Nº 0250, Buenos Aires, Argentina).

This is interesting indeed, and provides valuable insight into the behavior o Clarín, the strongest news presence in Argentina. It also serves as a background canvas to introduce the next section which discusses the relationship between the public and media agendas.

Figure 2

Clarin's market share in main businesses

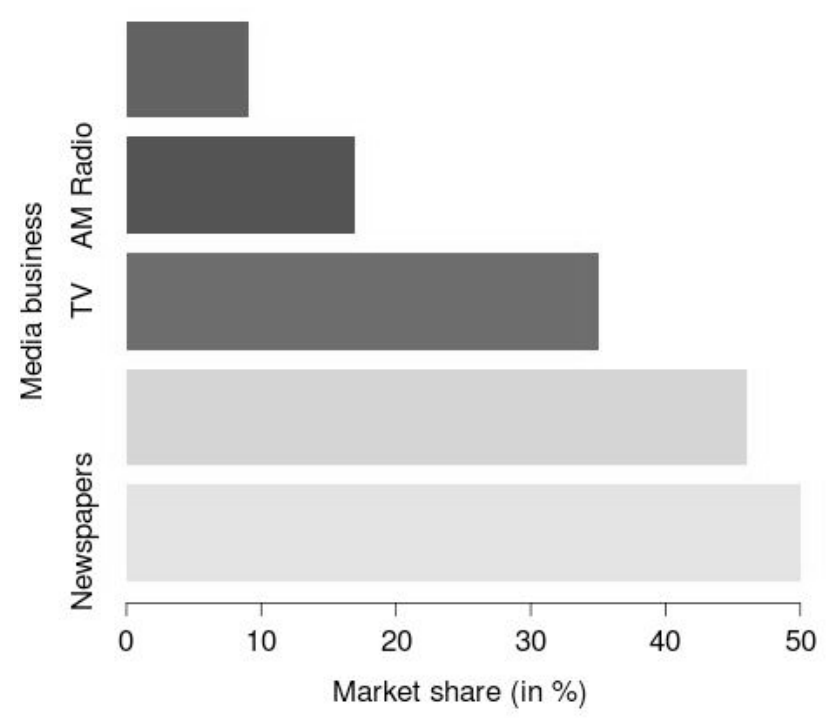

Source: Revista NOTICIAS, Número 1680, 7 de Marzo 2009, Editorial PERFIL. 


\section{THE MEDIA, PUBLIC AND POLICY AGENDAS}

Agenda-setting is a process whereby different institutional actors draw attention to specific problems purposedly aiming to gaugue public perceptions on policy alternatives outlined around those problems. Issues that come to the fore this way are often said to be salient and often become those which are considered important in public opinion -i.e security issues, economic conditions and political stability to mention but a few.

Similarly, issue management is an essential element in modern democracies, and it is most probably the hardest part of a President's job. Whatever the ruling party communicates on a specific issue will be interpreted by media outlets, which will in one form or another and to some larger or smaller degree affect the public perception and interpretation of said issue.

Media companies output is a voice in the news; a way of depicting reality according to a filter that each company applies as desired. The result of the news reporting viewed in the lens of each company is what that organization adds to the media agenda, constructed as the sum of the "lens views" of all media companies. Larger media conglomerates will most likely have a stronger say, and therefore might be able to influence agendas more than smaller local companies. In the end, what interests us is the way issues are portrayed in relevant media, since these lens views matter every time we can apply them to a specific case, i.e., an issue.

People, who consume media in all sorts and forms, also react in specific ways to specific stimuli and are likely to form an opinion around hot issues; such opinions, usually captured by public opinion polls, form the public agenda. In most countries, the public agenda is best depicted in the "most relevant issues" poll.

The president must manage the complexity of information flow and that becomes a very grainy issue when a president does not have a good relationship with media conglomerates. Whatever a President says will probably be interpreted the wrong way and affect the media portrayal of the story, thus generating some degree of possible confusion across the public. It becomes almost impossible to control the public reactions -which ultimately result in approval ratings for the government- when the media companies are out of control. In a democracy, this situation is acceptable because media benefit from freedom of speech and should be 
allowed to interpret issues any legitimate way they want, since the government should be focused on its treatment of issues as opposed to the public's reactions. When a government cares more about the reactions than managing issues, there is a problem to be dealt with.

Finally, there is the policy agenda which involves issues that are considered relevant by policymakers ${ }^{3}$. There are multiple agendas depending on the type of policymaking process involved. Some of the most important policy agendas are those of the President, the Congress and the Supreme Court's agenda. These agendas can be easily identified from their daily activities and official communications and also from keeping records of implemented policies. Naturally, it is quite possible that the policy agenda is related with the media agenda and even with the public agenda; that is why it is important to study these different agendas and their relationships rather than as isolated phenomena.

\section{RELATED LITERATURE AND HYPOTHESES}

The seminal contribution in the theory of agenda-setting by McCombs and Shaw (1972) on Chapel Hill voters was quickly followed by a host of empirical studies searching for evidence of agenda-setting effects. These early empirical studies were concerned with finding a causal relationship going from the coverage of issues in the media (media agenda) to the priorities of the public (public agenda). Despite using similar methods and approaches, the cumulative results of this stream of empirical research are not entirely unambiguous. While several studies [McCombs and Shaw (1972), Funkhouser (1973), Smith (1987)] found evidence of media effects on the public agenda, results are less clear in other studies and even suggest that the causation may actually run opposite to what is expected. In a way, this is hardly surprising considering that most of these studies rely on cross-section correlations where the results are likely to be affected by context-dependence.

The agenda-setting hypothesis essentially conveys a dynamic process since issues come and go and so does public interest echoing the "issue-attention cycle" described by Downs (1972). It is because of this that time series data are better suited to detect and estimate agenda-setting

3. The policy agenda is also known as political agenda. 
effects in this type of studies. Studies using dynamic tests yield more robust and significant findings on the relationship between the public agenda and the intensity and timing of the coverage of different issues by the news media [Funkhouser (1973), MacKuen and Coombs (1981)]. An alternative approach that also introduces dynamic considerations is used in Iyengar et al. (1982). This paper conducted several experiments where they systematically manipulated the news media agenda in order to see whether it was a driver of public attention. They found strong evidence supporting the view that the news media is very effective at telling people what to think and care about.

More recent literature has explored a variety of related issues including the joint evolution of the different agendas, political bias by the mass media and the relationship between news and economic and confidence indicators ${ }^{4}$. Blood and Phillips (1995) use several time series to analyze the relationships among news coverage, consumer sentiment and presidential popularity. The authors find some evidence suggesting that the media does indeed play a role in the evolution of the other variables; in particular, they find that there was an adversarial press effect. Other recent studies find a significant media effect on the salience of issues such as unemployment in the UK (Soroka, 2002), illegal inmigration in the US across both border and non-border states (Dunaway et al., 2007) and views of foreign nations by citizens in the US (Wanta et al., 2004).

Our work fits within the more recent literature in that we are interested in exploring the relationship between several variables of interest over time. Although we are primarly interested in testing the hypothesis that the print media influenced to some extent the public agenda, we also investigate whether there were any evidence of media malady -the effect of negative economic news on the economy- and whether the media influenced the public's perception and approval of the ruling administration. Summing up our hypotheses, in this work we test:

1- The proposition that there were media effects, in particular, that the media variables (ktotal, ecototal, and poltotal) are related with the variables capturing the public agenda (icg) and their serial correlation structure;

2- The proposition that economic news are related with several leading economic indicators (emae, ipc, ibankrate, pubexpend).

4. For recent work on political bias of the news media see Larcinese et al. (2007). 


\section{Methodology, data AND Results}

We use a time series approach to examine our hypotheses. First, we examine the series individually. Secondly, we test for cointengration between the series that represent our variables of interest. We then analyze causality between the series and we provide some additional robustness tests.

In particular we apply the Johansen cointegration approach [Johansen (1988), Johansen (1991)]. The empirical analysis of cointegration is based on the vector error correction model with p-lags VECM(p) with a constant restricted to lie in the cointegration space:

$$
\Delta x_{t}=\sum_{i=1}^{p-1} \Gamma_{i} \Delta x_{t-i}+\alpha \beta^{\prime} x_{t-1}+\mu_{0}+\varepsilon_{t}
$$

where $x_{t}$ is a vector of endogenous variables, $\mu_{0}=\alpha \beta_{0}+\alpha \perp \gamma_{0}$, so that $\beta_{0}$ is an intercept in the cointegration relations and $\gamma_{0}$ (a linear time trend) is equal to zero.

Our data comes from different sources. Firstly, the variables measuring the monthly newspaper mentions of the former President come from the source data used in the compilation of Universidad de Palermo's Observador de Medios $(\mathrm{OdM})^{5}$. We group mentions in three categories: those that refer to former President Nestor Kirchner, those that refer to economic issues and those that refer to political issues ${ }^{6}$. In addition to recording the total number of newspapers mentions, we also provide a qualitative dimension by assessing whether the news are portrayed in optimistic, neutral or pessimistic light. This is important since it will allows us to explore the relationship between both the quantity and quality of newspaper mentions and our selected indicators.

5. Information about sources, methodology and construction of the series is given in the appendix. Additional information about indicators is available at http://www.palermo.edu/econo micas/observador.html

6. The following topics were used to code the newspaper mentions. Economic news: private debt restructuring, inflation, agreement with the IMF, stock market swings, dollar, wage increases, engery crisis, intervention of Aerolíneas Argentinas, employment, and public services tariffs. Political news: agricultural blockade and export duties, elections in ciudad de Buenos Aires, picket lines, pulp-mill issues, insecurity, national elections, Senate kickbacks scandal, ley de superpoderes, and the Cromagnon tragedy. 
Table 1

Table of summary statistics

\begin{tabular}{|c|c|c|c|c|c|c|}
\hline VARIABLE & Oвs & MiN & Median & Mean & MAX & StD. DEV. \\
\hline kneu & 67 & 0.0 & 4.0 & 4.1 & 13.0 & 2.7 \\
\hline kopt & 67 & 0.0 & 3.0 & 3.5 & 14.0 & 3.0 \\
\hline kpes & 67 & 0.0 & 3.0 & 4.2 & 12.0 & 3.1 \\
\hline ktotal & 67 & 1.0 & 11.0 & 11.8 & 27.0 & 6.6 \\
\hline eco & 67 & 9.0 & 35.0 & 35.8 & 56.0 & 9.4 \\
\hline econeu & 67 & 2.0 & 8.0 & 10.0 & 33.0 & 5.9 \\
\hline ecoopt & 67 & 1.0 & 13.0 & 12.1 & 28.0 & 6.4 \\
\hline ecopes & 67 & 2.0 & 14.0 & 13.7 & 27.0 & 4.9 \\
\hline pol & 67 & 21.0 & 41.0 & 42.9 & 71.0 & 12.6 \\
\hline polneu & 67 & 6.0 & 16.0 & 17.1 & 47.0 & 6.8 \\
\hline polopt & 67 & 0.0 & 7.0 & 7.5 & 22.0 & 5.3 \\
\hline polpes & 67 & 4.0 & 18.0 & 18.3 & 36.0 & 7.0 \\
\hline imgpos & 67 & 20.0 & 60.0 & 58.1 & 83.0 & 14.5 \\
\hline imgreg & 67 & 9.0 & 28.0 & 27.1 & 38.0 & 6.0 \\
\hline imgneg & 67 & 1.0 & 9.0 & 12.8 & 46.0 & 10.5 \\
\hline$i c g$ & 67 & 1.2 & 2.4 & 2.3 & 3.3 & 0.5 \\
\hline icggov & 67 & 0.2 & 0.5 & 0.5 & 0.7 & 0.1 \\
\hline icgint & 67 & 0.2 & 0.4 & 0.4 & 0.7 & 0.1 \\
\hline icgexp & 67 & 0.2 & 0.4 & 0.4 & 0.6 & 0.1 \\
\hline icghon & 67 & 0.4 & 0.5 & 0.5 & 0.6 & 0.0 \\
\hline icgpro & 67 & 0.3 & 0.7 & 0.6 & 0.9 & 0.1 \\
\hline emae & 67 & 100.6 & 137.1 & 137.2 & 172.3 & 19.4 \\
\hline$i p c$ & 67 & 67.1 & 83.5 & 83.6 & 103.7 & 12.0 \\
\hline iratefirms & 67 & 5.4 & 9.1 & 10.7 & 32.6 & 5.7 \\
\hline ibankrate & 67 & 1.2 & 6.7 & 5.9 & 15.2 & 3.5 \\
\hline pubexpend & 67 & 5498.2 & 9557.8 & 10231.1 & 24935.2 & 3480.8 \\
\hline
\end{tabular}

Note: For a description of the variables, coverage and data sources see Appendix 
Secondly, we use the Indice de Confianza en el Gobierno (ICG) from the Universidad Torcuato di Tella measuring the confidence in government. Finally, we use indicators measuring the President's approval ratings available on a monthly basis from Poliarquia ${ }^{7}$. Our sample starts in June 2003 and finishes in December 2008 yielding 67 observations for each variable. The description and details of the variables used in our study are given in the Appendix. Summary statistics for the variables in our study are given in Table $1^{8}$.

Figure 3 illustrates the series capturing the media activity 9 . The upper diagram shows the three series for optimistic (kopt), neutral (kneu), and pessimistic (kpes) mentions associated with former President Néstor Kirchner. The middle diagram shows the same categories but for the number of economic news. Finally, the lower diagram shows the time series for the number of media mentions of political issues. Although there is no clear trend in the evolution of the number of optimistic Presidential mentions, the variable peaks during the second half of 2003 (shortly after the 2003 Presidential election) and looks to be rather stable around its average until the second half of 2007 where the next general election was held. The total number of President mentions follows a similar pattern with a surge in the number of mentions during first semester of 2006 (probably due in part to the active role in the cancellation of the debt with the IMF). Concerning economic news, the pattern of evolution is clearer as there seems to be a gradual increase of pessimistic economic news throughout Nestor Kirchner's mandate ${ }^{10}$. This seems to be supported by a decreasing number of optimist economic news. The evolution of political news is not so clear, however, although there seems to be a higher frequency of pessimist political news during the latter part of Kirchner's rule.

Figure 4 illustrates the cross-correlation functions between pairs of selected variables. Again, the purpose in including several variables which we do not include in the cointegration analysis is primarily descriptive

7. The data, methodology and notes concerning these indicators can be accesed at http://www.utdt.edu and http://www.poliarquia.com, respectively.

8. This table produces summary statistics for all the variables in our original dataset although we use a smaller subset in our econometric analysis. The information for the variables not used in the cointegration analysis is presented here merely for descriptive purposes.

9. Although we only use the total number of mentions for each category of media activity, we include the individual series which make up the total number of mentions. One reason for doing this is to check for changes in the patterns of the individual series and changes in the aggregate series.

10. Despite Argentina's sustained growth from 2003 to 2008, there were growing concerns about rising inflation and a gradual deterioration of the fiscal balance 
and may also serve as a motivation for the choice of variables for the econometric analysis. From this figure, we can observe both their contemporaneous correlation and correlation over time. As expected, there seems to be a strong and significant contemporaneous correlation (at lag 0) between optimistic newspapers mentions of the President and optimistic mentions of political and economics news. We observe a similar contemporaneous correlation between pessimistic mentions of the three series considered (although the correlation is not significant between kpes and ecopes). The strong contemporaneous correlation between mentions of the

Figure 3

News mentions of former President Kirchner, Economic and Political news.
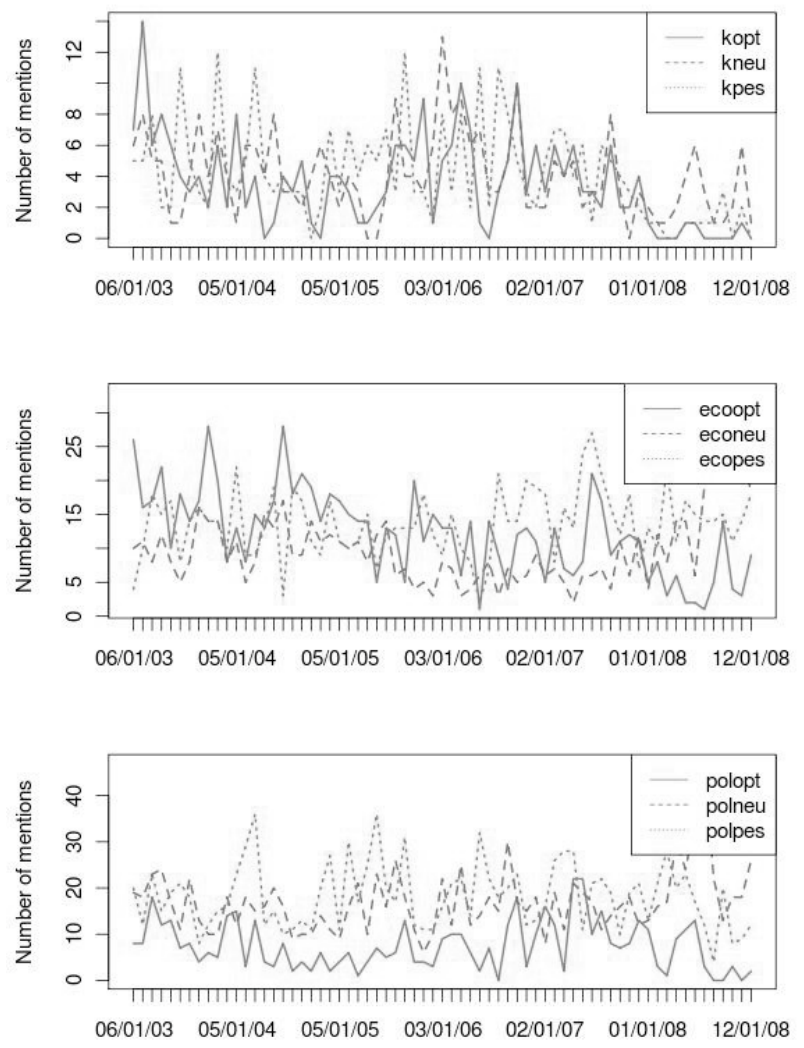

Source: Own elaboration. 
President and icg (confidence in government) and imgpos (president approval rating) is also quite evident from the graph although there is also significant correlation between the two series over through time, particularly within the range of up to 5 periods (months). The same result holds for pessimistic mentions of the President and imgneg (negative image of the President). Finally, we observe the presence of strong contemporaneous correlation and correlation through time between economic optimistic economic news and both variables proxying for the President's image and confidence in the administration.

Figure 4

Cross-correlation functions between selected variables.
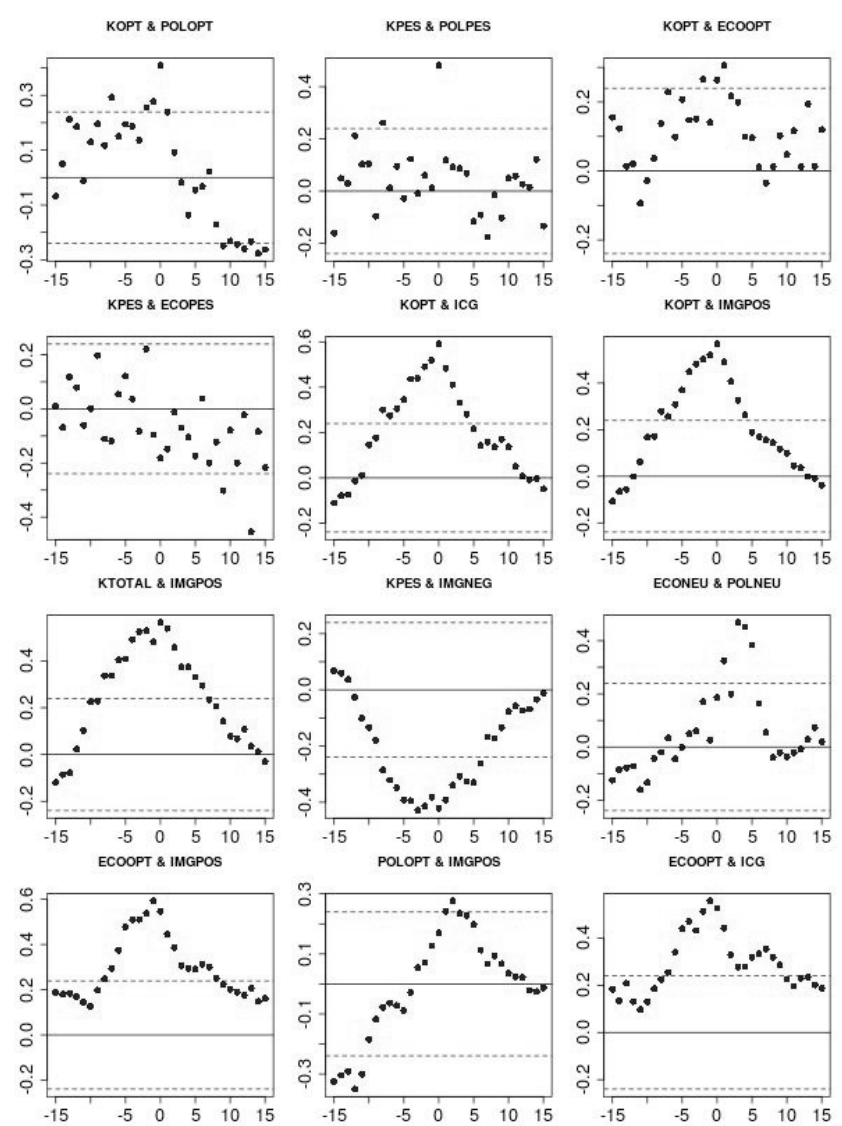

Source: Own elaboration. 
Table 2

Test for the cointegrating rank, Trace test

\begin{tabular}{cccccc}
\hline P-R & R & Eig.Value & Trace & Frac95 & P-Value \\
\hline $\mathbf{4}$ & 0 & 0.357 & 66.851 & 62.704 & 0.002 \\
$\mathbf{3}$ & 1 & 0.265 & 38.193 & 36.192 & 0.021 \\
$\mathbf{2}$ & 2 & 0.172 & 18.145 & 17.175 & 0.095 \\
$\mathbf{1}$ & 3 & 0.086 & 5.873 & 5.611 & 0.208 \\
\hline
\end{tabular}

One important aspect that needs to be discussed here is the most suitable econometric approach that allows us to deal effectively with the hypothesis and questions posed in the previous section. Given that our primary interest is to explore the long-run relationship between the different agendas, it would be sensible to use an approach suited to estimate the empirical correlations dealing effectively with the time-series issues. Although an important part of the recent empirical literature on agenda-setting combines the use of simple empirical correlations with ARIMA methods, we believe that cointegration models and methods are better suited to capture the nature and characteristics of the data. We use a multivariate statistical model to test for the hypothesis 1 and 2 in section 4 . First, we analyse whether there is a long run relationship between the variables ktotal, ecototal, poltotal (capturing the media agenda) and icg (the main variable capturing the public agenda). We specify an unrestricted vector autoregression (VAR) with 2 lags. We have also included 11 centered seasonal dummies to control for seasonality effects. We have run some preliminary tests at the multivariate and univariate level to check for diagnosis, i.e., normality, heteroskedasticity and autocorrelation, and we find that the model with 2 lags is correctly specified, see Table 3 . After that we test for the number of cointegrating relationships amongst our four subset of variables. The results are reported in Table 2.

Table 3

Multivariate misspecification tests

\begin{tabular}{|c|c|c|c|c|}
\hline "Autocorrelation : Ljung-Box & $\mathrm{x}^{2}(224)=$ & 384.444 & p-val. & 0.001 \\
\hline $\mathrm{LM}_{1}$ & $x^{2}(16)=$ & 40.165 & p-val. & 0.001 \\
\hline $\mathrm{LM}_{2}$ & $x^{2}(16)=$ & 26.597 & p-val. & 0.046 \\
\hline Normality & $x^{2}(8)=$ & 7.821 & p-val. & 0.451 \\
\hline ARCH : LM 1 & $x^{2}(100)=$ & 116.694 & p-val. & 0.119 \\
\hline $\mathrm{LM}_{2}$ & $x^{2}(100)=$ & 225.218 & p-val. & 0.107 \\
\hline
\end{tabular}


According to Table 2 we cannot reject the null hypothesis that there are 2 cointegrating vectors in our cointegration space. Next, we test for long run exclusion, stationarity and weak exogeneity. The results from these tests are reported in Table 4.

\section{Table 4}

Tests for long run exclusion, stationarity and weak exogeneity

LR-test, Chi-Square(r), P-values in brackets.

\begin{tabular}{|c|c|c|c|c|c|c|c|}
\hline \multicolumn{8}{|c|}{ TEST OF EXCLUSION } \\
\hline $\bar{r}$ & DGF & 5\% C.V. & ICG & KTOTAL & "ECOTOTAL & POLTOTAL & CONSTANT \\
\hline 1 & 1 & 3.841 & $\begin{array}{l}2.029 \\
{[0.154]}\end{array}$ & $\begin{array}{l}1.208 \\
{[0.272]}\end{array}$ & $\begin{array}{l}2.084 \\
{[0.149]}\end{array}$ & $\begin{array}{l}6.989 \\
{[0.008]}\end{array}$ & $\begin{array}{l}3.638 \\
{[0.056]}\end{array}$ \\
\hline 2 & 2 & 5.991 & $\begin{array}{l}9.693 \\
{[0.008]}\end{array}$ & $\begin{array}{l}8.816 \\
{[0.012]}\end{array}$ & $\begin{array}{l}2.156 \\
{[0.340]}\end{array}$ & $\begin{array}{l}14.063 \\
{[0.001]}\end{array}$ & $\begin{array}{l}5.773 \\
{[0.056]}\end{array}$ \\
\hline 3 & 3 & 7.815 & $\begin{array}{l}11.805 \\
{[0.008]} \\
\end{array}$ & $\begin{array}{c}15.199 \\
{[0.002]}\end{array}$ & $\begin{array}{l}8.165 \\
{[0.043]}\end{array}$ & $\begin{array}{c}20.413 \\
{[0.000]}\end{array}$ & $\begin{array}{l}11.840 \\
{[0.008]}\end{array}$ \\
\hline
\end{tabular}

LR-test, Chi-Square(4-r), P-values in brackets.

TEST OF STATIONARITY

\begin{tabular}{rrrcccc}
\hline \hline $\mathrm{r}$ & DGF & 5\% C.V. & \multicolumn{1}{c}{ ICG } & KTOTAL & ECOTOTAL & POLTOTAL \\
\hline 1 & 3 & 7.815 & 21.689 & 18.243 & 16.359 & 3.780 \\
& & & {$[0.000]$} & {$[0.000]$} & {$[0.001]$} & {$[0.286]$} \\
2 & 2 & 5.991 & 13.559 & 9.967 & 8.597 & 2.714 \\
& \multirow{2}{*}{1} & \multirow{2}{*}{3.841} & 5.790 & $60.007]$ & {$[0.014]$} & {$[0.257]$} \\
& & & {$[0.016]$} & {$[0.013]$} & 0.860 & 1.881 \\
\hline
\end{tabular}

Restricted Constant included in the cointegrating relation(s).

LR-Test, Chi-Square(r), P-values in brackets.

TEST OF WEAK EXOGENEITY

\begin{tabular}{rrrcccc}
\hline \hline $\mathrm{r}$ & DGF & 5\% C.V. & ICG & KTOTAL & ECOTOTAL & POLTOTAL \\
\hline 1 & 1 & 3.841 & 0.018 & 1.033 & 2.318 & 8.609 \\
2 & 2 & & {$[0.892]$} & {$[0.309]$} & {$[0.128]$} & {$[0.003]$} \\
2.991 & 2.625 & 8.804 & 2.558 & 16.367 \\
3 & \multirow{2}{*}{3} & \multirow{2}{*}{7.815} & $3.269]$ & {$[0.012]$} & {$[0.278]$} & {$[0.000]$} \\
& & & {$[0.358]$} & 10.394 & 8.463 & 22.167 \\
\hline
\end{tabular}


According to this table, for $\mathrm{r}=2$, the variable ecototal appears not to be significant in the cointegrating space. Also, we find that the variable poltotal is stationary around a drift. Finally, the weak exogeneity tests imply that the only endogenous variables in our model are ktotal and poltotal. This implies that the remaining variables are not explained by this model. Now, in Table 5 we display the identified cointegrating vectors.

Table 5

Estimated cointegrating vectors

\begin{tabular}{|c|c|c|c|c|c|}
\hline \multicolumn{6}{|c|}{$\overline{\beta^{\prime}}$} \\
\hline & ICG & KTOTAL & ECOTOTAL & POLTOTAL & CONSTANT \\
\hline Beta(1) & 0.000 & 0.000 & 0.000 & 1.000 & -42.227 \\
\hline Beta(2) & -8.664 & 1.000 & 0.221 & 0.000 & 0.000 \\
\hline
\end{tabular}

Table 6

Test for the cointegrating rank, Trace test

\begin{tabular}{cccccc}
\hline P-R & R & Eig.Value & Trace & Frac95 & P-Value \\
\hline $\mathbf{5}$ & 0 & 0.484 & 105.521 & 76.813 & 0.000 \\
$\mathbf{4}$ & 1 & 0.356 & 62.565 & 25.313 & 0.006 \\
$\mathbf{3}$ & 2 & 0.241 & 33.941 & 11.023 & 0.067 \\
$\mathbf{2}$ & 3 & 0.174 & 16.005 & 6.011 & 0.177 \\
$\mathbf{1}$ & 4 & 0.054 & 3.613 & 1.605 & 0.484 \\
\hline
\end{tabular}

The first vector implies that poltotal is a stationary variable around a constant. The second cointegrating vector implies that ktotal depends positively on icg and negatively on ecototal. These results suggest that there is evidence of a media effect; interestingly, the interpretation of this result is that the President approval ratings (measured by icg) were positively influenced by the total number of newspaper mentions during this period, regardless of them being optimistic, neutral or pessimistic. This may ultimately be explained by how people weigh optimistic or 
pessimistic mentions -it would appear that the tone of pessimistic mentions was not as extreme as to induce individuals to attach a negative opinion of the President. Finally, in order to check for the stability of the cointegrating space, we have plotted the recursive test by Hansen and S. Johansen (1999) for the beta parameters, likelihood ratio and eigen values. Following the authors the representation is more relevant when checking the stability of the models, given that the recursive estimation is performed by means of keeping fixed the dynamics. From Figure 5, we can see that there are no problems of stability in neither the forward and backward estimation, since the $\mathrm{R}$ representation of the tests is below unity, during most of the sample.

Regarding the second hypothesis, we first report in Table 7 some specification tests, which indicate that no further action needs to be taken. We also report in Table 6 the Trace test for the cointegration rank amongst the variables ecototal, emae, ipc, ibankrate and pubexpend.

Accordingly, the evidence suggest that there are 2 cointegrating vectors. We display in Table 8 the tests for long run exclusion, stationarity and weak exogeneity.

Table 7

Multivariate misspecification tests

\begin{tabular}{lllll}
\hline \hline Autocorrelation : Ljung-Box & $\mathrm{X}^{2}(350)=$ & 394.154 & p-val. & 0.052 \\
$\mathrm{LM}_{1}$ & $\mathrm{X}^{2}(25)=$ & 27.994 & p-val. & 0.308 \\
$\mathrm{LM}_{2}$ & $\mathrm{X}^{2}(25)=$ & 22.994 & p-val. & 0.632 \\
\hline Normality & $\mathrm{X}^{2}(8)=$ & 7.821 & p-val. & 0.451 \\
\hline $\mathrm{ARCH}: \mathrm{LM} 1$ & $\mathrm{X}^{2}(225)=$ & 236.462 & p-val. & 0.287 \\
$\mathrm{LM}_{2}$ & $\mathrm{X}^{2}(450)=$ & 438.988 & p-val. & 0.636 \\
\hline \hline
\end{tabular}


Table 8

Tests for long run exclusion, stationarity and weak exogeneity

LR-test, Chi-Square(r), P-values in brackets.

\begin{tabular}{|c|c|c|c|c|c|c|c|c|}
\hline \multicolumn{9}{|c|}{ TEST OF EXCLUSION } \\
\hline $\mathrm{r}$ & DGF & 5\% C.V. & "ECOTOTAL & EMAE & IPC & IBANKRATE & PUBEXPEND & CONSTANT \\
\hline 1 & 1 & 3.841 & $\begin{array}{l}10.031 \\
{[0.002]}\end{array}$ & $\begin{array}{l}9.658 \\
{[0.002]}\end{array}$ & $\begin{array}{l}7.415 \\
{[0.006]}\end{array}$ & $\begin{array}{l}0.843 \\
{[0.359]}\end{array}$ & $\begin{array}{l}0.229 \\
{[0.632]}\end{array}$ & $\begin{array}{l}0.094 \\
{[0.759]}\end{array}$ \\
\hline 2 & 2 & 5.991 & $\begin{array}{c}20.444 \\
{[0.000]}\end{array}$ & $\begin{array}{c}16.859 \\
{[0.000]}\end{array}$ & $\begin{array}{c}11.849 \\
{[0.003]}\end{array}$ & $\begin{array}{l}5.617 \\
{[0.060]}\end{array}$ & $\begin{array}{l}0.796 \\
{[0.672]}\end{array}$ & $\begin{array}{l}0.149 \\
{[0.928]}\end{array}$ \\
\hline 3 & 3 & 7.815 & $\begin{array}{l}22537 \\
{[0.000]}\end{array}$ & $\begin{array}{c}22.404 \\
{[0.000]}\end{array}$ & $\begin{array}{l}17.077 \\
{[0.001]}\end{array}$ & $\begin{array}{l}6.155 \\
{[0.104]}\end{array}$ & $\begin{array}{l}5.952 \\
{[0.114]}\end{array}$ & $\begin{array}{l}1.472 \\
{[0.689]}\end{array}$ \\
\hline 4 & 4 & 9.488 & $\begin{array}{c}31.228 \\
{[0.000]}\end{array}$ & $\begin{array}{c}28.163 \\
{[0.000]}\end{array}$ & $\begin{array}{c}25.837 \\
{[0.000]}\end{array}$ & $\begin{array}{c}14.785 \\
{[0.005]}\end{array}$ & $\begin{array}{c}10.411 \\
{[0.034]}\end{array}$ & $\begin{array}{l}6.761 \\
{[0.149]}\end{array}$ \\
\hline
\end{tabular}

LR-test, Chi-Square(5-r), P-values in brackets.

\begin{tabular}{|c|c|c|c|c|c|c|c|}
\hline \multicolumn{8}{|c|}{ TEST OF STATIONARITY } \\
\hline $\bar{r}$ & DGF & 5\% C.V. & ECOTOTAL & EMAE & IPC & IBANKRATE & PUBEXPEND \\
\hline 1 & 4 & 9.488 & $\begin{array}{c}16.033 \\
{[0.003]}\end{array}$ & $\begin{array}{c}24.789 \\
{[0.000]}\end{array}$ & $\begin{array}{c}25.927 \\
{[0.000]}\end{array}$ & $\begin{array}{c}26.421 \\
{[0.000]}\end{array}$ & $\begin{array}{c}27.609 \\
{[0.000]}\end{array}$ \\
\hline 2 & 3 & 7.815 & $\begin{array}{l}8.606 \\
{[0.035]}\end{array}$ & $\begin{array}{c}15.482 \\
{[0.001]}\end{array}$ & $\begin{array}{c}16.126 \\
{[0.001]}\end{array}$ & ${ }_{[0.001]}^{15.893}$ & $\begin{array}{c}17.789 \\
{[0.000]}\end{array}$ \\
\hline 3 & 2 & 5.991 & $\begin{array}{l}5.350 \\
{[0.069]}\end{array}$ & $\begin{array}{c}21.276 \\
{[0.000]}\end{array}$ & $\begin{array}{l}8.453 \\
{[0.015]}\end{array}$ & $\begin{array}{l}8.732 \\
{[0.013]}\end{array}$ & $\begin{array}{l}9.580 \\
{[0.008]}\end{array}$ \\
\hline 4 & 1 & 3.841 & $\begin{array}{l}1.909 \\
{[0.167]}\end{array}$ & $\begin{array}{l}6.987 \\
{[0.008]}\end{array}$ & $\begin{array}{l}8.638 \\
{[0.003]}\end{array}$ & $\begin{array}{l}8.434 \\
{[0.004]}\end{array}$ & $\begin{array}{l}8.215 \\
{[0.004]}\end{array}$ \\
\hline
\end{tabular}

Restricted Constant included in the cointegrating relation(s). LRTest, Chi-Square(r), P-values in brackets.

TEST OF WEAK EXOGENEITY

\begin{tabular}{|c|c|c|c|c|c|c|c|}
\hline $\bar{~} \mathrm{r}$ & "DGF & 5\% C.V. & ECOTOTAL & EMAE & IPC & IBANKRATE & P PUBEXPEND \\
\hline 1 & 1 & 3.841 & $\begin{array}{l}5.696 \\
{[0.017]}\end{array}$ & $\begin{array}{l}0.027 \\
{[0.869]}\end{array}$ & $\begin{array}{c}11.686 \\
{[0.001]}\end{array}$ & $\begin{array}{l}0.619 \\
{[0.432]}\end{array}$ & $\begin{array}{l}0.603 \\
{[0.437]}\end{array}$ \\
\hline 2 & 2 & 5.991 & $\begin{array}{c}14.583 \\
{[0.001]}\end{array}$ & $\begin{array}{l}1.054 \\
{[0.590]}\end{array}$ & $\begin{array}{c}18.769 \\
{[0.000]}\end{array}$ & $\begin{array}{l}0.901 \\
{[0.637]}\end{array}$ & $\begin{array}{l}6.639 \\
{[0.036]}\end{array}$ \\
\hline 3 & 3 & 7.815 & $\begin{array}{l}19.469 \\
{[0.000]}\end{array}$ & $\begin{array}{l}6.425 \\
{[0.093]}\end{array}$ & $\begin{array}{c}21.677 \\
{[0.000]}\end{array}$ & $\begin{array}{l}0.975 \\
{[0.807]}\end{array}$ & $\begin{array}{c}12.171 \\
{[0.007]}\end{array}$ \\
\hline 4 & 4 & 9.488 & $\begin{array}{c}20.838 \\
{[0.000]}\end{array}$ & $\begin{array}{c}10.457 \\
{[0.033]}\end{array}$ & $\begin{array}{c}24.534 \\
{[0.000]}\end{array}$ & $\begin{array}{l}9.634 \\
{[0.047]}\end{array}$ & $\begin{array}{c}14.746 \\
{[0.005]}\end{array}$ \\
\hline
\end{tabular}

According to Table 8 we find that pubexpend and the drift are not significant in the cointegrating space. Also we find that the only endogenous variables are ecototal, ipc and pubexpend. Finally we report the identified cointegrating space in Table 9.

The first cointegrating vector implies that ecototal is positively related to emae and negatively related to ibankrate and ipc. The second cointegrating vector implies that ipc is positively related to ecototal, emae, ipc and ibankrate. This results support our second hypothesis about the existence of a strong relationship over time between the media agenda, 
more specifically the economic news chapter, and several leading economic indicators. In particular, it seems that the total number of economic news is positively influenced by the monthly indicator of economic activity and negatively influenced by the interbank lending rate and the inflation rate ${ }^{11}$. We have also performed the Hansen and Johansen (1999) stability tests, which are displayed in Figure 6. We can see that there are no problems of stability in neither the forward and backward estimation, since the $\mathrm{R}$ representation of the tests is below unity, during most of the sample.

Table 9

Estimated cointegrating vectors

\begin{tabular}{lcrcccc}
\hline \hline & \multicolumn{7}{c}{$\beta^{\prime}$} \\
\hline \hline Beta(1) & ECOTOTAL & EMAE & IPC & IBANKRATE & PUBEXPEND & CONSTANT \\
Beta(2) & -0.1600 & -3.353 & 4.738 & 0.630 & 0.000 & 0.000 \\
\hline
\end{tabular}

\section{Conclusions}

In this paper we test the hypothesis of the existence of media effects on the public priorities and on selected economic indicators. Using previously unavailable data for the period 2003-2008, we find support for our two hypotheses. Interestingly, our analysis would seem to suggest that during this period the total number of newspaper mentions of the President influenced the public perception and approval of the President. Moreover, our analysis suggest that the relationship between these variables is strong and stable over time during the period analyzed. Our work presents fresh evidence of significant media effects on public perceptions during the administration of Nestor Kirchner. Finally, we also find evidence of a strong relationship between the newspaper mentions of economic news and various leading economic indicators.

\section{REFERENCES}

Bavastro, R. and Szusterman, C. (2003). "The congressional elections in argentina, 2001”. Electoral Studies, 22 pp 352-360(9).

11. Unfortunately, we were not able to test for the cointegration of the three series, namely the media agenda, the public agenda and the economic indicators, due to a loss in the degrees of freedom. 
Blood, D. J. and Phillips, P. C. B. (1995). "Recession headline news, consumer sentiment, the state of the economy and presidential popularity: A time series analysis 1989-1993". International Journal of Public Opinion Research, 7(1):2-22.

Brosius, H.-B. and Kepplinger, H. M. (1990). "The Agenda-Setting Function of Television News: Static and Dynamic Views". Communication Research, 17(2):183-211.

Downs, A. (1972). "Up and down with ecology -the 'issue-attention cycle"”. Public Interest, 28:38-50.

Dunaway, J., Abrajano, M., and Branton, R. (2007). "Agenda setting, public opinion, and the issue of inmigration reform". Available at SSRN: http://ssrn.com/abstract=1017846.

Eaton, H. (1989). “Agenda-setting with bi-weekly data on content of three national media". Journalism Quarterly, 66, pp. 942- 948.

Funkhouser, G. R. (1973). "The issues of the sixties: An exploratory study in the dynamics of public opinion". The Public Opinion Quarterly.

Hansen, H. and S. Johansen (1999). "Some tests for parameter constancy in cointegrated VAR-models". Econometrics Journal, 2(2):306-333.

Iyengar, S., Peters, M. D., and Kinder, D. R. (1982). "'Not-so-minimal' consequences of tv news programs". The American Political Science Review, 76(4):848-858.

Johansen, S. (1988). "Statistical analysis of cointegrated vectors". Journal of Economic Dynamics and Control, 12(2-3):231-254.

Johansen, S. (1991). "Estimation and hypothesis of cointegration vectors in gaussian vector autoregressive models". Econometrica, 59(6):1551-1580.

King, P. (1994). "Issue agendas in the 1992 Taiwan legislative election". $\mathrm{PhD}$ thesis, University of Texas at Austin.

Larcinese, V., Puglisi, R., and Snyder, J. M. J. (2007). "Partisan bias in economic news: Evidence on the agenda-setting behavior of U.S. newspapers". Working paper 13378, National Bureau of Economic Research, Inc.

MacKuen, M. J. and Coombs, S. L. (1981). More than news: media power in public affairs. Beverly Hills: Sage. 
McCombs, M. E. and Shaw, D. L. (1972). "The agenda-setting function of mass media". The Public Opinion Quarterly, 36(2):176-187.

McCombs, M. E. and Shaw, D. L. (1977). "The emergence of american political issues: The agenda-setting function of the press". In McCombs, M. E. and Shaw, D. L., editors, The agenda-setting function of the press. St. Paul, MN: West.

Rey Lennon, F. (1998). "Argentina: 1997 elecciones. los diarios nacionales y la campaña electoral". Report by The Freedom Forum and Austral University.

Smith, K. A. (1987). "Effects of Newspaper Coverage on Community Issue Concerns and Local Government Evaluations". Communication Research, 14(4):379-395.

Soroka, S. N. (2002). "When does news matter? agenda-setting for unemployment in the UK". Working paper 2002-w7, Nuffield College Politics.

Waisbord, S. R. (1993). "A sign of the times: Television and electoral politics in Argentina, 1983-1989". Technical Report 190, Helen Kellogg Institute for International Studies.

Wanta, W., Golan, G., and Lee, C. (2004). "Agenda setting and international news: Media influence on public perceptions of foreign nations". Journalism and Mass Comunication Quarterly, 81(2). 


\section{APPENDIX}

\begin{tabular}{|c|c|c|}
\hline VARIABLE & DESCRIPTION & SOURCE \\
\hline KNEU & $\begin{array}{l}\text { Number of neutral monthly newspaper mentions } \\
\text { of former President Kirchner. Includes all } \\
\text { mentions whose wording does not suggest } \\
\text { optimism or pessimism }\end{array}$ & $\begin{array}{l}\text { Observador de Medios available } \\
\text { at http:www. palermo.edu/econo } \\
\text { micas/ observador.html }\end{array}$ \\
\hline KOPT & $\begin{array}{l}\text { Number of optimistic monthly newspaper } \\
\text { mentions of former President Kirchner. Includes } \\
\text { all mentions cast in a positive light and tone. }\end{array}$ & $\begin{array}{l}\text { Observador de Medios available } \\
\text { at http:www. palermo.edu/econo } \\
\text { micas/observador.html }\end{array}$ \\
\hline KPES & $\begin{array}{l}\text { Number of pessimistic monthly newspaper } \\
\text { mentions of former President Kirchner. } \\
\text { Includes all mentions cast in a negative } \\
\text { light and tone. }\end{array}$ & $\begin{array}{l}\text { Observador de Medios } \\
\text { available at http:www.paler } \\
\text { mo.edu/economicas/ } \\
\text { observador.html }\end{array}$ \\
\hline KTOTAL & $\begin{array}{l}\text { Number of total monthly newspaper mentions of } \\
\text { formar Pres- ident Kirchner }\end{array}$ & $\begin{array}{l}\text { Observador de Medios available } \\
\text { at http:www.palermo.edu/econo } \\
\text { micas/observador.html }\end{array}$ \\
\hline ECONEU & $\begin{array}{l}\text { Number of neutral monthly newspaper mentions of } \\
\text { economic issues. Includes all mentions whose } \\
\text { wording does not suggest optimism or pessimism }\end{array}$ & $\begin{array}{l}\text { Observador de Medios available } \\
\text { at http:www.palermo. } \\
\text { edu/economicas/observador.html }\end{array}$ \\
\hline ECOOPT & $\begin{array}{l}\text { Number of optimistic monthly newspaper mentions } \\
\text { of economic issues. Includes all mentions cast in a } \\
\text { positive light and tone. }\end{array}$ & $\begin{array}{l}\text { Observador de Medios available } \\
\text { at http:www.palermo.edu/econo } \\
\text { micas/observador.html }\end{array}$ \\
\hline ECOPES & $\begin{array}{l}\text { Number of pessimistic monthly newspaper mentions } \\
\text { of economic issues. Includes all mentions cast in a } \\
\text { negative light and tone. }\end{array}$ & $\begin{array}{l}\text { Observador de Medios available } \\
\text { at http:www.palermo.edu/econo } \\
\text { micas/observador.html }\end{array}$ \\
\hline ECOTOTAL & $\begin{array}{l}\text { Number of total monthly newspaper mentions of } \\
\text { economic issues }\end{array}$ & $\begin{array}{l}\text { Observador de Medios available } \\
\text { at http:www.palermo.edu/econo } \\
\text { micas/observador.html }\end{array}$ \\
\hline POLNEU & $\begin{array}{l}\text { Number of neutral monthly newspaper mentions of } \\
\text { political issues. Includes all mentions whose wording } \\
\text { does not suggest optimism or pessimism }\end{array}$ & $\begin{array}{l}\text { Observador de Medios available } \\
\text { at http:www.palermo.edu/econo } \\
\text { micas/observador.html }\end{array}$ \\
\hline POLOPT & $\begin{array}{l}\text { Number of optimistic monthly newspaper mentions } \\
\text { of political issues. Includes all mentions cast in a } \\
\text { positive light and tone. }\end{array}$ & $\begin{array}{l}\text { Observador de Medios available } \\
\text { at http:www.palermo.edu/econo } \\
\text { micas/ observador.html }\end{array}$ \\
\hline POLPES & $\begin{array}{l}\text { Number of pessimistic monthly newspaper mentions } \\
\text { of political issues. Includes all mentions cast in a } \\
\text { negative light and tone. }\end{array}$ & $\begin{array}{l}\text { Observador de Medios available } \\
\text { at http:www.palermo.edu/econo } \\
\text { micas/observador.html }\end{array}$ \\
\hline POLTOTAL & $\begin{array}{l}\text { Number of total monthly newspaper mentions } \\
\text { of political issues }\end{array}$ & $\begin{array}{l}\text { Observador de Medios available } \\
\text { at http:www.palermo.edu/econo } \\
\text { micas/observador.html }\end{array}$ \\
\hline IMGPOS & $\begin{array}{l}\text { President's positive image (persons having a } \\
\text { positive image of the President out of } 100 \text { ) }\end{array}$ & Poliarquía Consultores \\
\hline IMGNEG & $\begin{array}{l}\text { President's negative image (persons having a } \\
\text { negative image of the President out of 100) }\end{array}$ & Poliarquía Consultores \\
\hline ICG & $\begin{array}{l}\text { Composite index of confidence in the government. } \\
\text { Ranges from } 0 \text { (lowest confidence in government) } \\
\text { to } 5 \text { (highest confi-dence in government) }\end{array}$ & $\begin{array}{l}\text { Indice de Confianza en el } \\
\text { Gobierno, Escuela de Gobierno } \\
\text { Universidad Torcuato di Tella. } \\
\text { www.utdt.edu }\end{array}$ \\
\hline
\end{tabular}




\begin{tabular}{|c|c|c|}
\hline VARIABLE & DESCRIPTION & SOURCE \\
\hline ICG_GOV & $\begin{array}{l}\text { General assessment component of the } \\
\text { icg. Ranges from } 0 \text { (very bad) to } 5 \\
\text { (very good) }\end{array}$ & $\begin{array}{l}\text { Indice de Confianza en el Gobierno, } \\
\text { Escuela de Gobierno - Universidad } \\
\text { Torcuato di Tella. tp://www.utdt.edu }\end{array}$ \\
\hline ICG_INT & $\begin{array}{l}\text { Pro-general interest component of the } \\
\text { icg. Ranges from } 0 \text { (cares for specific } \\
\text { interest) to } 5 \text { (cares for general interest) }\end{array}$ & $\begin{array}{l}\text { Indice de Confianza en el Gobierno, } \\
\text { Escuela de Gobierno - Universidad } \\
\text { Torcuato di Tella. tp://www.utdt.edu }\end{array}$ \\
\hline ICG_EXP & $\begin{array}{l}\text { Efficiency of public expenditure com } \\
\text { ponent of the icg. Ranges from } 0 \text { (very } \\
\text { inefficient) to } 5 \text { (very efficient) }\end{array}$ & $\begin{array}{l}\text { Indice de Confianza en el Gobierno, } \\
\text { Escuela de Gobierno - Universidad } \\
\text { Torcuato di Tella. tp://www.utdt.edu }\end{array}$ \\
\hline ICG_HON & $\begin{array}{l}\text { Degree of corruption component of the } \\
\text { icg. Ranges from } 0 \\
\text { (very corrupt) to } 5 \text { (very honest) }\end{array}$ & $\begin{array}{l}\text { Indice de Confianza en el Gobierno, } \\
\text { Escuela de Gobierno - Universidad } \\
\text { Torcuato di Tella. tp://www.utdt.edu }\end{array}$ \\
\hline ICG_PRO & $\begin{array}{l}\text { Problem-solving capability component } \\
\text { of the icg. Ranges from } 0 \text { (government } \\
\text { does not solve problems) to } 6 \text { (govern } \\
\text { ment solves problems) }\end{array}$ & $\begin{array}{l}\text { Indice de Confianza en el Gobierno, } \\
\text { Escuela de Gobierno - Universidad } \\
\text { Torcuato di Tella. tp://www.utdt.edu }\end{array}$ \\
\hline EMI & Monthly estimator of industrial activity & INDEC. http://www.indec.mecon.gov.ar \\
\hline EMAE & Monthly estimator of industrial activity & INDEC. http://www.indec.mecon.gov.ar \\
\hline IPC & Consumer Price Index & INDEC. http://www.indec.mecon.gov.ar \\
\hline PUBEXPEND & Central Government expenditures & INDEC. http://www.indec.mecon.gov.ar \\
\hline IBANKRATE & Interbank lending rate & $\begin{array}{l}\text { Banco Central de la República } \\
\text { Argentina. http://www.bcra.gov.ar }\end{array}$ \\
\hline
\end{tabular}


Figure 5

Stability tests. Source: Own elaboration
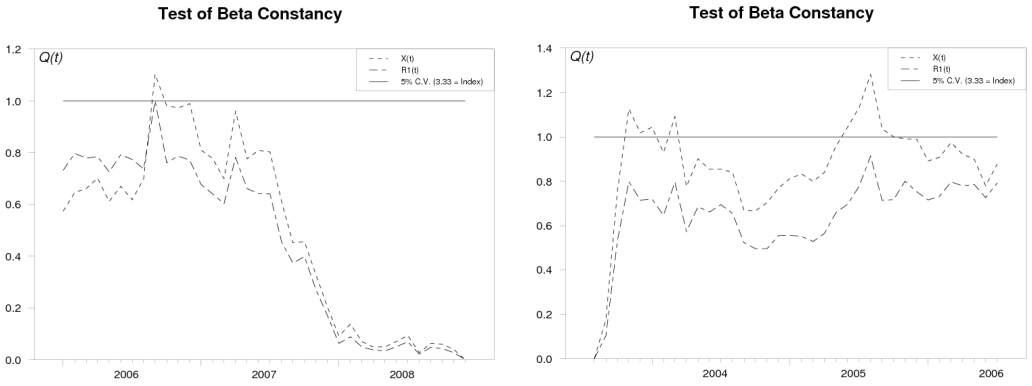

(a) Beta constancy, forward estimation

(b) Beta constancy, backward estimation
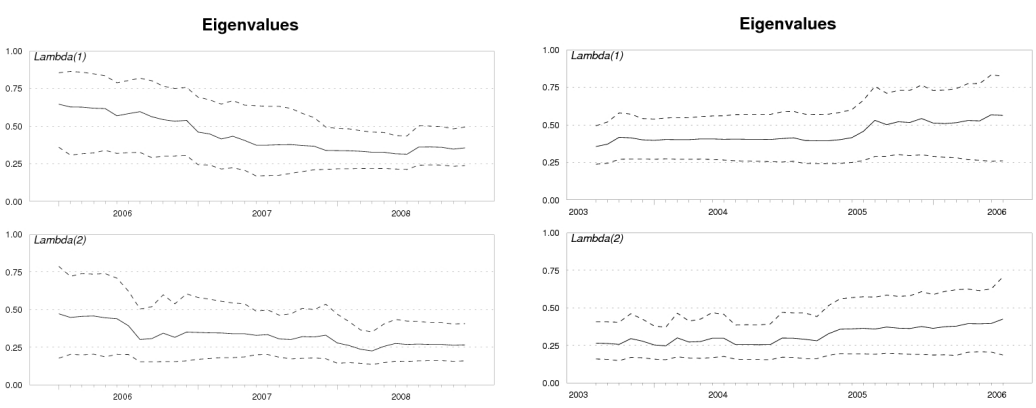

(c) Eigen values constancy, forward

(d) Eigen values constancy, backward
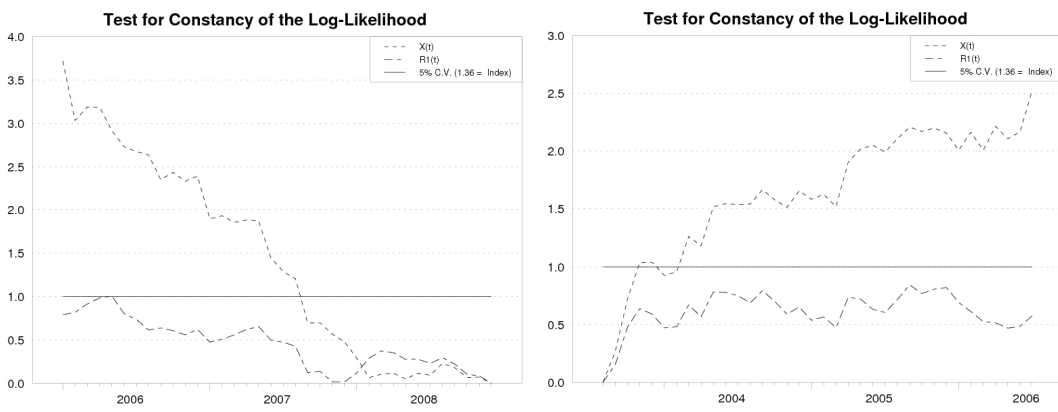

(e) Likelihood ration constancy, forward

(f) Likelihood ration constancy, backward 


\section{Figure 6}

\section{Stability tests. Source: Own elaboration}

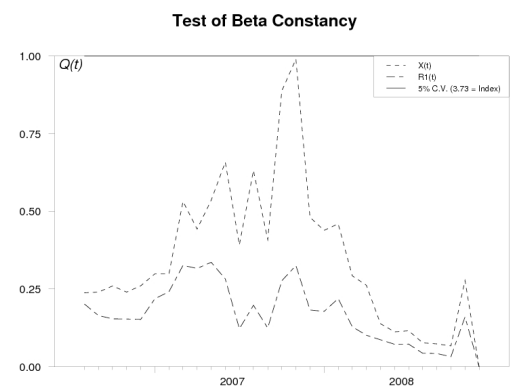

(a) Beta constancy, forward estimation

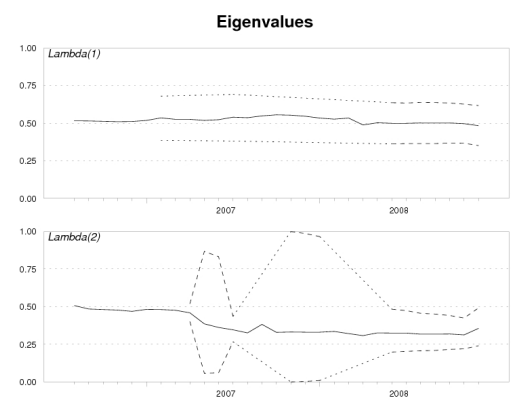

(c) Eigen values constancy, forward

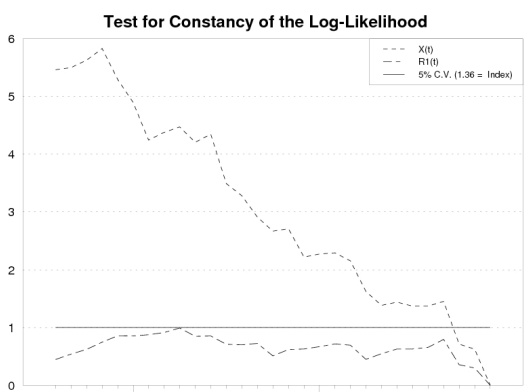

(e) Likelihood ration constancy, forward

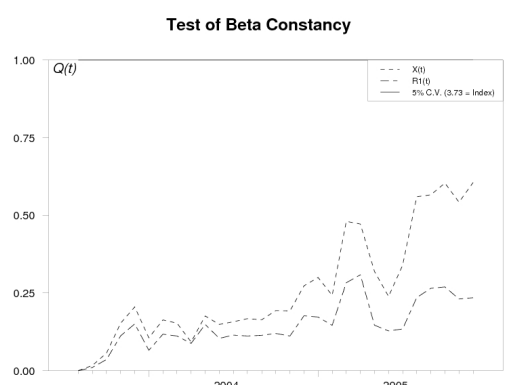

(b) Beta constancy, backward estimation

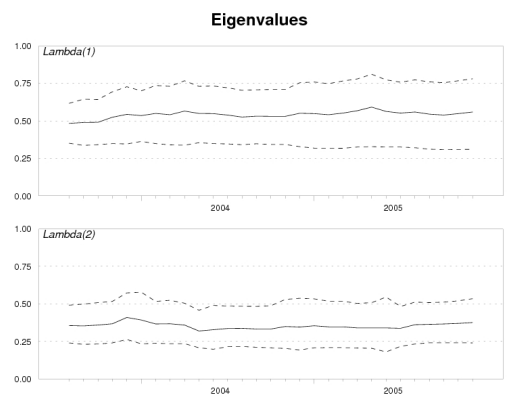

(d) Eigen values constancy, backward

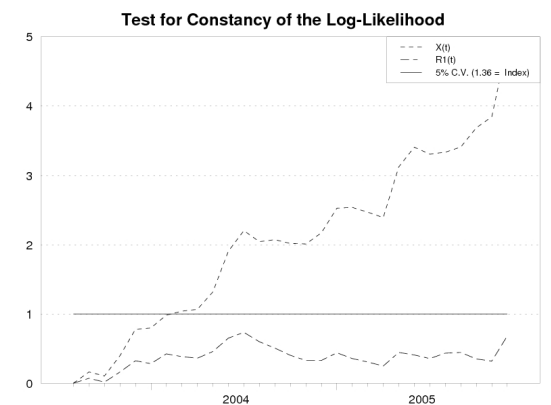

(f) Likelihood ration constancy, backward 